University of South Carolina

Scholar Commons

1981

\title{
Channel Instability in a Braided Sand Bed River
}

William L. Graf

University of South Carolina-Columbia, grafw@mailbox.sc.edu

Follow this and additional works at: https://scholarcommons.sc.edu/geog_facpub

Part of the Geography Commons

\section{Publication Info}

Published in Water Resources Research, Volume 17, Issue 4, 1981, pages 1087-1094.

http://www.agu.org/journals/wr/

(C) 1981 by American Geophysical Union

This Article is brought to you by the Geography, Department of at Scholar Commons. It has been accepted for inclusion in Faculty Publications by an authorized administrator of Scholar Commons. For more information, please contact digres@mailbox.sc.edu. 


\title{
Channel Instability in a Braided, Sand Bed River
}

\author{
WILLIAM L. GRAF \\ Department of Geography, Arizona State University, Tempe, Arizona 85281
}

\begin{abstract}
The Gila River of central Arizona is representative of braided, sand bed rivers in alluvial valleys that have inherent unstable behavior and destructive channel migration. The 112-year record of channel conditions along a portion of the Gila River provides data for the construction of locational probability maps for main flow channels. Zones of stability and hazardous instability alternate with each other at 3.2 $\mathrm{km}(2 \mathrm{mi})$ intervals. During the past century the overall sinuosity of the main flow channel has remained close to 1.18, despite numerous changes in actual location. Spatial and temporal variation of sinuosity have occurred in subreaches as a result of sedimentation behind a dam and fluctuations in the density of phreatophyte growth, which both affect the hydraulics of flood flows. Unstable zones of the channel correspond to the surface of the sediment wedge behind the dam and areas dense phreatophyte growth. Stable zones correspond to areas controlled by bedrock or man-made structures, as well as locations determined by these external factors plus the requirement to maintain a consistent sinuosity. Channels such as that of the Gila River do not meet most assumptions of equilibrium and are best understood through probabilistic approaches with an assumption of catastrophic adjustment.
\end{abstract}

\section{INTRODUCTION}

Economic development, population growth, and changing land use patterns are common characteristics of river valleys in the basin and range province of the American Southwest. Once a nearly empty corner of a developing nation, the alluvial basins of the Southwest are now the focal points of a massive economic and demographic shift from the industrial and agricultural states of the East and Midwest. The unstable river channels of alluvial basins in Utah, Nevada, southern California, and especially central Arizona pose difficult flood hazards, particularly since hydraulic, engineering, and geomorphic principles developed elsewhere seem not to be useful in river management and planning in the developing region. Frequent, wide-ranging, and destructive channel migration is a common feature of rivers that must be clearly defined and adequately explained before the initiation of successful engineering works or management plans (Figures 1 and 2).

On a geologic time scale, the rivers of the interior American Southwest are aggrading [Hunt, 1974]. Debris from fault block mountains are transported to the basins and added to alluvial and lacustrine fills thousands of meters deep. The faults dividing the basins from the mountains are still active in some areas, but in central Arizona they have not exhibited movement for several million years [Euge et al., 1978]. The rivers delivering the sediments exhibit courses across the basins that have general braided characteristics. A single low-flow or main flow channel with one or two more shallow overflow channels is common, rather than the nearly equal multiple channels of braided streams on the Great Plains [Smith, 1971]. Under natural conditions, banks of the Southwestern rivers are frequently poorly defined.

All the rivers of the southwestern basins have been affected by human activities, however, so that none is presently in its natural state. Extensive irrigation works with retention and diversion structures insure that all the streams now have altered flow regimes with reduced annual discharges. An example of the magnitude of these works is provided by Smith [1972]. Sand and gravel mines to provide materials for economic development are frequently located in channel areas. Bridges, pipe crossings, and channelization works contribute

Copyright $\odot 1981$ by the American Geophysical Union. to altered conditions, and human disruption of riparian vegetation results in channel and near-channel plant communities unlike any experienced prior to 1850 [for example, see Turner, 1974].

While the resource values of the riverine environments have attracted development to the rivers, the unpredictable behavior of the streams has made them hazardous environments [Graf, 1980]. In two recent floods, high water and channel migration resulted in over $\$ 100$ million in damages along the Salt and Gila Rivers of central Arizona [Corps of Engineers, $1979 a, b]$. Recent flooding and attending channel instability have led to the definition of two problems addressed in this paper. First, channel migration does not seem to affect the entire channel length equally, and instability is spatially variable. Hazardous unstable zones need to be defined before effective corrective efforts can be made. How can channel instability be mapped in braided, sand bed channels?

The second problem involves explaining the observed pattern of stability so that more reliable predictions are possible for a variety of engineering and management alternatives. Why are the stable and unstable zones distributed the way they are?

The Gila River in Maricopa County, central Arizona, provides a convenient river that has abundant data and that is representative of braided, sand bed rivers found in the American Southwest. The study area occurs in an area of deep alluvium-filled valleys surrounded by mountains of basaltic, crystalline, sedimentary rocks [Wilson, 1962]. The $56.4 \mathrm{~km}$ (35 mi) reach of the Gila River between the Salt River and Gillespie Dam (Figure 3) has a sandy bed underlain by gravel lenses, a migrating main flow channel about $60 \mathrm{~m}$ (200 ft) wide, and a high-flow channel up to $1.6 \mathrm{~km}(1 \mathrm{mi})$ wide. Historical photographs show that the area behind Gillespie Dam was silted in within two years of the dam closure in 1921, and the wedge of sediments continues to grow. Banks are poorly defined, especially for the high-flow channel. Low Pleistocence terraces border some portions of the channels [Péwé, 1978], and erosional residuals of sedimentary or crystalline rocks protrude through the alluvial fill in some places [Wilson et al., 1957]. Mesquite, cottonwood, and willow originally dominated the riparian vegetation in the near-channel areas, but reduced surface flows, fluctuating groundwater levels, human manipu- 


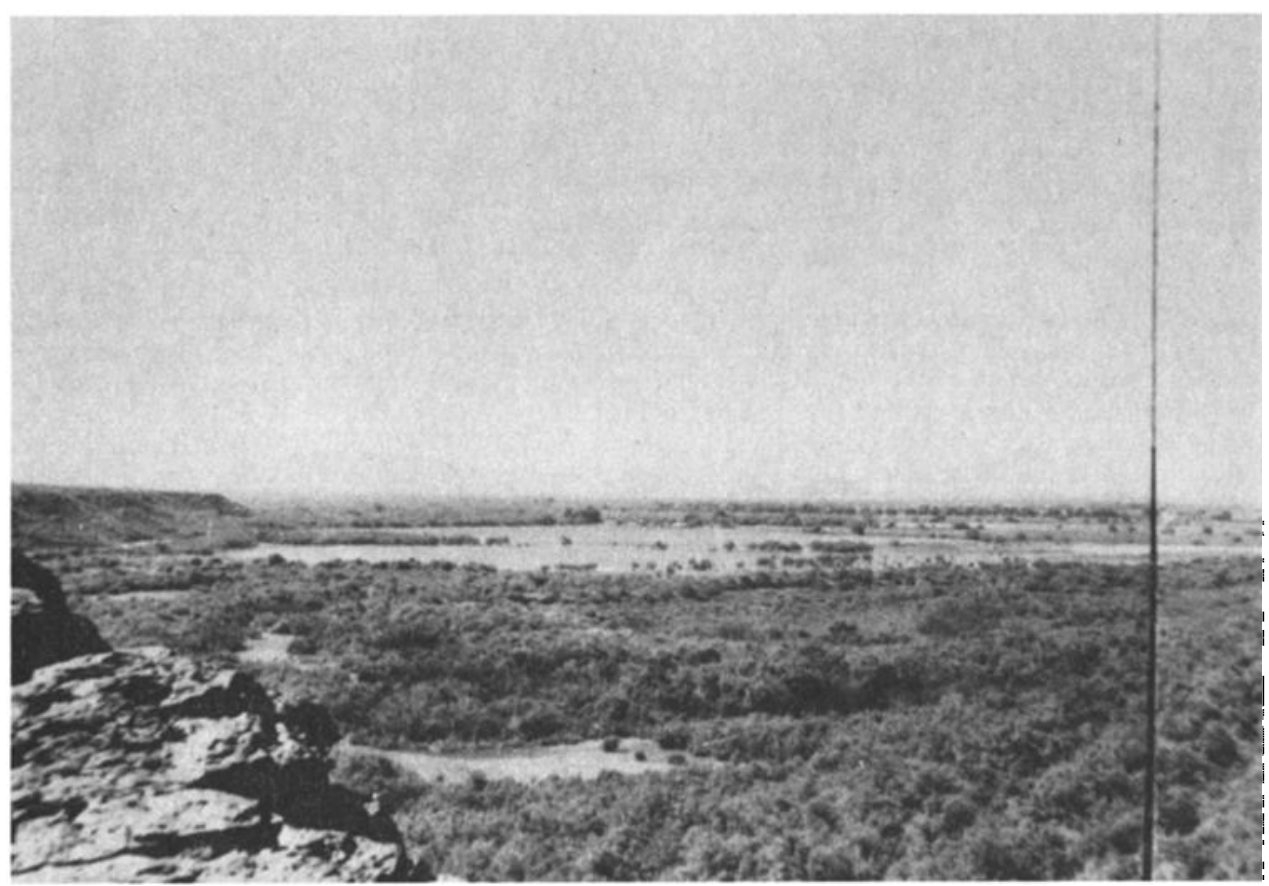

Fig. 1. View north along the western side of the Gila Valley, about $2.9 \mathrm{~km}$ (1.5 mi) upstream from Gillespie Dam (see Figure 3 for location). The main flow channel in this July 1949 view is out of the picture to the right. Tamarisk thicket in the foreground shows some lineations, but the main flow channel had not been in this area since before 1883. Compare with Figure 2. Photo by the then U. S. Bureau of Reclamation, held by the Phoenix Urban Studies Office, U.S. Army Corps of Engineers.

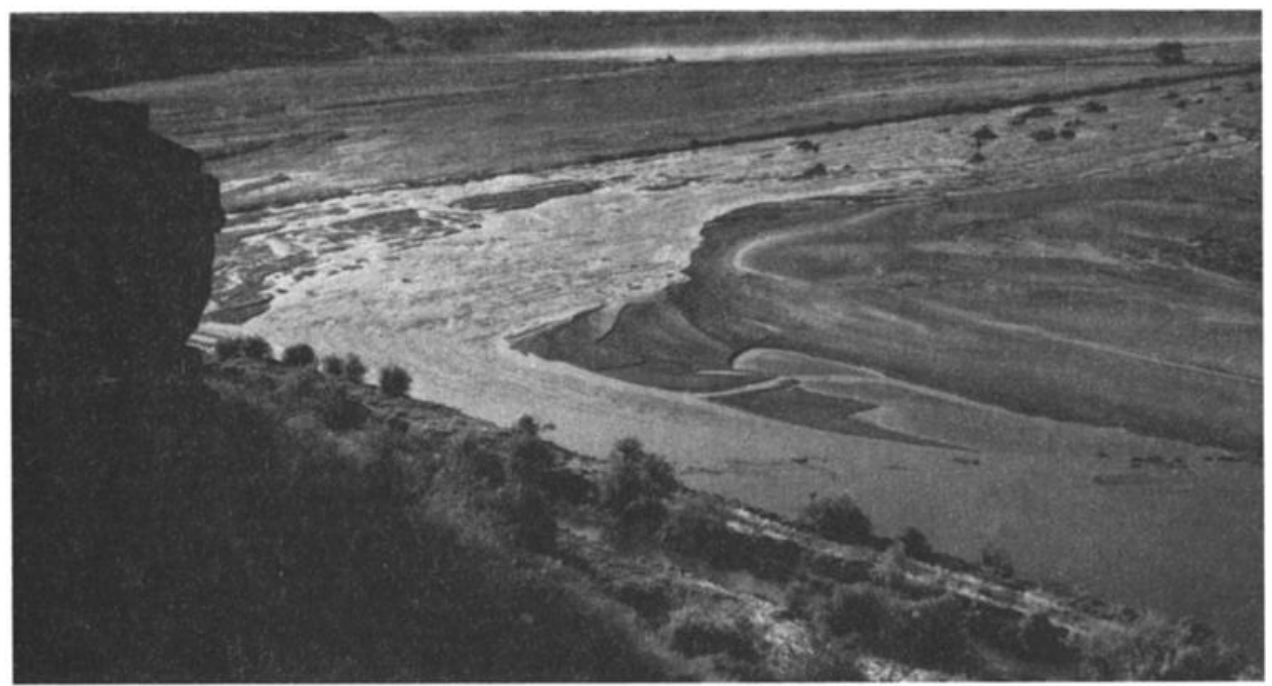

Fig. 2. Same view as Figure 1, as seen in April 1980. The main flow channel has been radically relocated by the February 1980 flood, and the leveled fields that replaced the tamarisk thickets have been destroyed. Photo by author.

lations, and the invasion of artificially introduced tamarisk have resulted in the appearance of new ecological communities. Extremely dense phreatophyte growth, mostly tamarisk, occurs in some areas.

The climate of the area is that of a hot, dry desert with a mean annual rainfall of $17.8 \mathrm{~cm}(7 \mathrm{in})$ and mean annual temperature of $29.4^{\circ} \mathrm{C}\left(85^{\circ} \mathrm{F}\right)$ [U.S. Department of Commerce, 1968]. Wide fluctuations of rainfall and temperatures are common, but under natural conditions the river maintained a continuous discharge that usually did not dip below $28 \mathrm{~m}^{3} \mathrm{~s}^{-1}$
(1000 $\left.\mathrm{ft}^{3} \mathrm{~s}^{-1}\right)$ based on inputs from the $128,700 \mathrm{~km}^{2}(49,650$ $\mathrm{mi}^{2}$ ) watersheds extending eastward to the mountains along the Arizona-New Mexico border [Halpenny and Green, 1975; Aldridge, 1970]. Extensive irrigation development has reduced the mean annual discharge (exclusive of flood flows) on the Salt River to zero and of the Gila River to $2.8 \mathrm{~m}^{3} \mathrm{~s}^{-1}(100$ $\mathrm{ft}^{3} \mathrm{~s}^{-1}$ ) or less. Floods have discharges that ranged from 8,400 $\left.\mathrm{m}^{3} \mathrm{~s}^{-1}\right)\left(300,000 \mathrm{ft}^{3} \mathrm{~s}^{-1}\right)$ in 1891 to $616 \mathrm{~m}^{3} \mathrm{~s}^{-1}\left(22,000 \mathrm{ft}^{3} \mathrm{~s}^{-1}\right)$ in 1973 (Table 1). The destructive migration of the main flow channel occurs only during flood events. 


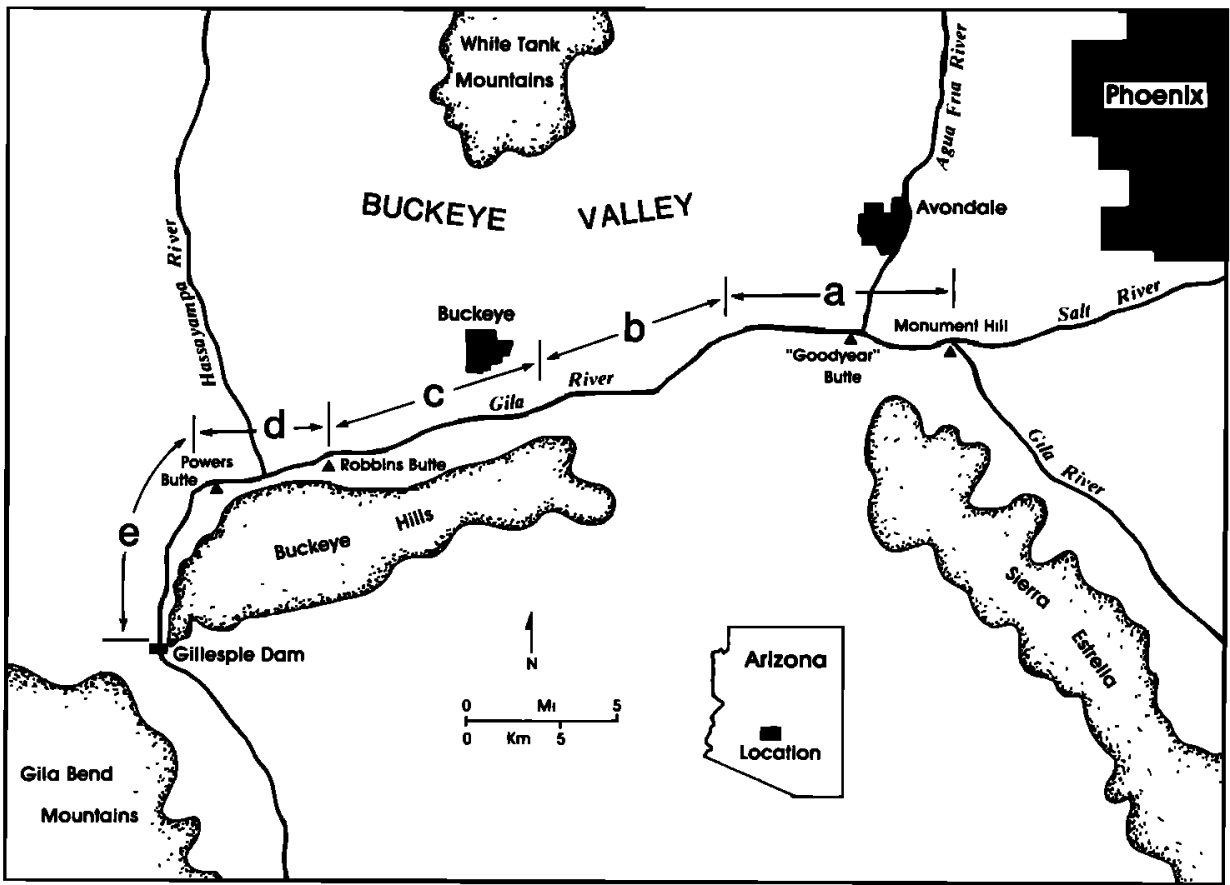

Fig. 3. General location map, Gila River from the Salt River to Gillespie Dam. Subsections defined by key letters correspond to locational probability maps in Figure 4a-e.

The remaining sections of this paper include a description of the methods used for mapping the instability of the main flow channel and a method used to describe and analyze the sinuosity of the main flow channel. Hazardous and stable zones are then discussed, with sinuousity providing an explanation of the spatial variation in channel stability. A concluding section outlines some reservations and problems, with a brief summary.

\section{METHODS}

Successful definition of stable and unstable portions of the channel in the study area depends on the analysis of a lengthy historical record because the changes occur only during infrequent floods. The number of floods determines the number of possible observed channel systems. The useful historical record extends from 1868 to 1980 , but there are some spatial and temporal gaps in the record. For the sake of convenience the study reach was arbitrarily divided into five subsections, with the historical data sources providing information on channel configurations 11-15 times in the last 112 years, depending on the subsection. The renditions of channel configurations are on plat maps, topographic maps, irrigation surveys, and aerial photographs, supplemented by historical ground photographs (Table 2).

The location of the main flow channel was transcribed from the original data sources to standard bases, resulting in maps with series of superimposed meandering lines representing a variety of channel locations. Sample lines were then constructed across the channel area at $1.6 \mathrm{~km}(1 \mathrm{mi})$ intervals orthogonal to the general trend of the channels. Each sample line crossing the channel area was divided into $165 \mathrm{~m} \mathrm{(500} \mathrm{ft)}$ segments, and the number of times a channel crossed each segment was tabulated. This number was converted to a percentage of all crossings of the sampling line, and the resulting percentage (hereafter considered a probability) was plotted at the center of the segment.

Thus far the procedure produced a series of maps, one for each subsection of the study reach. Each map showed lines of points at $1.6 \mathrm{~km}(1 \mathrm{mi})$ intervals along the channel, with each point assigned a value expressing the probability that a main flow channel had been located there during the past 112 years.

TABLE 1. Floods in the Salt and Gila River System in Central Arizona

\begin{tabular}{|c|c|c|}
\hline \multirow{2}{*}{$\begin{array}{c}\text { Date } \\
\text { Feb. } 1890\end{array}$} & \multicolumn{2}{|c|}{$\begin{array}{c}\text { Peak Discharge, } \\
\mathrm{m}^{3} \mathrm{~s}^{-1}\left(\mathrm{ft}^{3} \mathrm{~s}^{-1}\right)\end{array}$} \\
\hline & 4,004 & $(143,000)$ \\
\hline Feb. 1891 & 8,400 & $(300,000)$ \\
\hline April 1895 & 3,200 & $(115,000)$ \\
\hline April 1905 & 3,200 & $(115,000)$ \\
\hline Nov. 1895 & 5,600 & $(200,000)$ \\
\hline Jan. 1916 & 3,360 & $(120,000)$ \\
\hline Jan. 1916 & 2,940 & $(105,000)$ \\
\hline Feb. 1920 & 3,640 & $(130,000)$ \\
\hline Feb. 1927 & 1,960 & $(70,000)$ \\
\hline March 1938 & 2,380 & $(85,000)$ \\
\hline March 1941 & 1,120 & $(40,000)$ \\
\hline Jan. 1966 & 1,876 & $(67,000)$ \\
\hline Feb. 1973 & 616 & $(22,000)$ \\
\hline March 1978 & 3,416 & $(122,000)$ \\
\hline Dec. 1978 & 3,920 & $(140,000)$ \\
\hline Jan. 1979 & 2,464 & $(88,000)$ \\
\hline March 1979 & 1,887 & $(67,400)$ \\
\hline Feb. 1980 & 5,040 & $(180,000)$ \\
\hline
\end{tabular}

Note: Peak discharges on the Salt River at Phoenix are from unpublished data provided by U.S. Geological Survey, U.S. Forest Service, and newspaper accounts. They are indicative of relative flows in the study area. There are some additions to the reach from headwaters of the Gila, but these are relatively minor because of upstream control structures. Unknown flow attenuation is not accounted for. 
TABLE 2. Data Sources for Channel Locations of the Gila River From the Salt River to Gillespie Dam

\begin{tabular}{l} 
Year \\
\hline 1868 Plat map, Government Land Office Survey, by J. P. Ingalls \\
1883 Plat map, Government Land Office Survey, by R. C. Powers \\
1907 Plat map, Government Land Office Survey, by J. F. Hesse \\
1921 Plat map, Government Land Office Survey, by S. E. Blout \\
1926 Map of the Salt River Valley, by W. H. Becker \\
1929 Irrigation District Map, Salt River and Vicinity, by W. H. \\
Becker \\
1937 Aerial photographs, U.S. Soil Conservation Service \\
1941 Map, Salt River Valley and Maricopa County, by W. H. \\
Becker \\
1944 Irrigation Survey Map, by Gillespie Land and \\
Irrigation Company \\
1957 Aerial photographs, Agricultural Stabilization and \\
Conservation Service \\
1961 Aerial photographs, U.S. Geological Survey \\
1971 Aerial photographs, U.S. Geological Survey \\
1976 Aerial photographs, Arizona Department of Transportation \\
1979 Aerial photographs, Maricopa County Flood Control District \\
1980 Aerial photographs, Maricopa County Flood Control District
\end{tabular}

Additional sources of historical ground photos: Library of Congress Photo Collection, National Archives, Arizona State Historical Society, Salt River Project, U.S. Bureau of Reclamation, U.S. Army Corps of Engineers, Arizona Department of Game and Fish, and Arizona State University Library, Arizona Collection.

* Some sources provide only partial coverage.

These points provided the input for the final step in stability mapping: a contour map, with each contour connecting points of equal probability.

The final product was a series of probability maps, one for each subsection of the study area (Figure 4). Where probabilities are low, the channel is relatively unstable and is likely to be located in a new position each time a flood occurs. Where probabilities are high, the channel is relatively stable, and is likely to be located in the same place much of the time. The probability maps show that stable and unstable zones alternate with each other along the channel with probabilities ranging from zero to nearly $90 \%$.

Although the Gila River in the study area has a braided channel, its main flow channel is susceptable to sinuosity analysis which may be useful in describing changes in channel pattern [Leopold and Wolman, 1957]. Sinuosity has the added attraction of having been used in previous studies and so provides an opportunity for comparisons [Schumm, 1977]. Sinuosity is defined as the actual along-channel distance divided by the most direct along-valley distance. Previous research shows that sinuosity represents a method of gradient adjustment by the fluvial system in response to discharge and sediment characteristics [Schumm, 1963; Brice, 1974]. Typical values of sinuosity range from 1.0 (perfect alinement with the shortest possible distance) to over 2.0 (channel meandering so greatly that it is more than twice as long as the shortest possible distance).

In the study area sinuosity was calculated by measuring the actual along-channel distances on the transcribed traces from the historical sources and from recent observations. Sinuosity was calculated for the entire study reach as well as each subsection. The results are given in Table 3. The shortest overall distance for the study reach is about $48 \mathrm{~km}$ (30 mi), but over the last 112 years the main flow channel has had a mean length of approximately $57 \mathrm{~km}$ (35.5 mi). The shortest channel was $54.6 \mathrm{~km}$ ( $33.9 \mathrm{mi})$, and the longest was $58.6 \mathrm{~km}$ (36.4 mi).

\section{Discussion}

The probability maps (Figure $4 a-e$ ) provide a view of the main flow channel from a probabilistic perspective. The per- spective seems most appropriate for two reasons. First, fluvial processes are partly deterministic and partly stochastic [Shen, 1979]. Deterministic models may be appropriate for some aspects of research into fluvial processes of the Gila River, though a combination of approaches is most likely to meet with success. Second, most established hydraulic models contain a basic assumption of equilibrium, but the past century of change in the Gila River clearly demonstrates that except for general sinuosity, the channel is not in an equilibrium condition [Stevens et al., 1975], so that classic models are unlikely to be useful without radical modification [Prigogine, 1978]. For example, assumptions of Manning roughness coefficients in the unreasonable range of $\mathbf{0 . 7 5}$ or greater are required for an adequate 'fit' of descriptive models to observed conditions in the phreatophyte-infested channels. Since almost all major channel changes occur rapidly as a result of flood events, the application of catastrophe theory may be useful [Graf, 1979; Thornes, 1980].

An examination of the probability maps indicates that some sections of the channel are remarkably stable, despite changes in sinuosity from one time to the next. Each stable zone, indicated by areas of the high-value contours, is associated with a control factor. In Figure $4 a$, stable zones are found where the channel passes close to buttes or hills that are erosional remnants piercing the alluvial fill (Goodyear Butte and Powers Butte for examples). These buttes fill space that otherwise would be available for channel locations, so the system has fewer locational options in its operation. Similar controls are sharply defined near Robbins Butte and Powers Butte (Figure 4d). Human activities also act as control factors for stable zones, as indicated at a bridge crossing (U.S. 80/Arizona Route 85 crossing, Figure $4 c$ ), a road crossing (Jackrabbit Trail, Figure $4 b$ ), and a dam (Gillespie Dam, Figure $4 e$ ). In each case, engineering works have stabilized the channel location. Intentional efforts at stabilizing the channel location in the reach $11.3 \mathrm{~km}$ (7 mi) upstream from Gillespie Dam by clearing phreatophytes and shaping a straight channel have not been successful and have had no noticeable effect on channel instability as shown on the probability map.

The probability maps also reveal zones of stability not directly related to control factors, but that are the indirect consequences of limiting channel migration in some reaches. Even though the channel does not exhibit strong tendencies toward equilibrium, the sinuosity values do not deviate greatly from a mean value. Therefore, if a mean sinuosity is to be maintained, and if some portions of the channel are relatively immobile because of external controlling factors, the number of options possible for channel location away from the controlled sections is limited. Examples of these stable reaches resulting from the combined influences of external factors and sinuosity include a meandering zone of high probability between the U. S. 80/Arizona 85 crossing and Robbins Butte (Figure $4 c$ ), patches between Robbins and Powers Buttes (Figure 4d), and an area upstream from Gillespie Dam (Figure 4e).

Unstable zones are indicated by low-value contours on the probability maps, and they are located away from external control points in sections dominated by deep alluvial fill. One remarkable area is shown on the left edge of Figure $4 b$ and the right edge of Figure $4 c$, where a zone of zero probability is embedded in the center of the general channel area. This probability configuration shows that in the past 112 years, the main flow channel has never been located in the center, but always to one side or the other. Such an arrangement is probably required in the maintenance of sinuosity.

Human influences also account for some of the zones of in- 

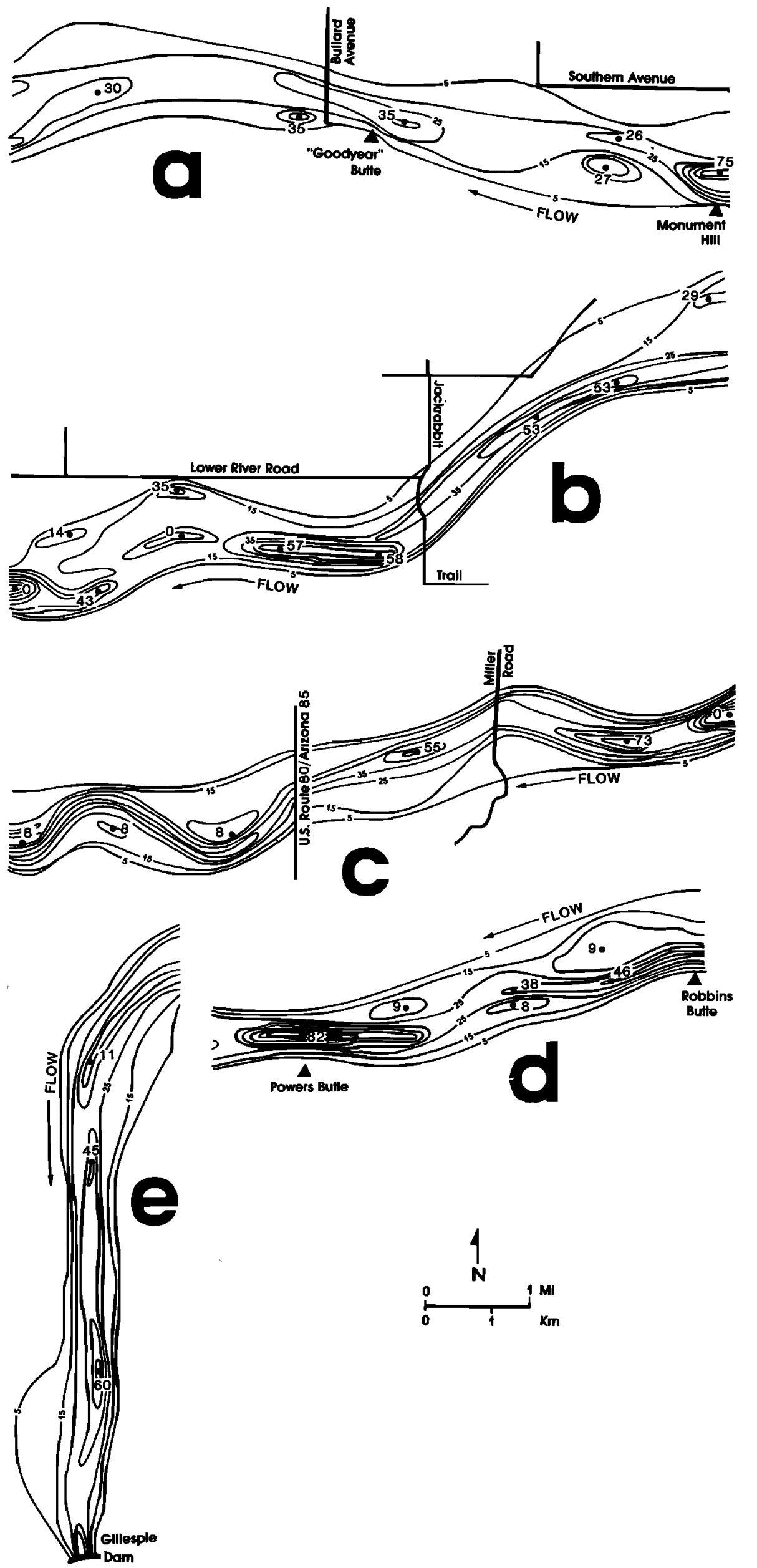

Fig. 4. Locational probability maps of the main flow channel of the Gila River from the Salt River to Gillespie Dam. See Figure 3 for corresponding subsections identified by key letters. 
TABLE 3. Sinuosity of the Main Flow Channel of the Gila River, From the Salt River to Gillespie Dam.

\begin{tabular}{|c|c|c|c|c|c|c|}
\hline Year & $\begin{array}{l}\text { (a) Monument Hill } \\
\text { to Cotton Road }\end{array}$ & $\begin{array}{l}\text { (b) Cotton Road } \\
\text { to Rainbow Road }\end{array}$ & $\begin{array}{l}\text { (c) Rainbow Road } \\
\text { to Robbins Butte }\end{array}$ & $\begin{array}{l}\text { (d) Robbins Butte } \\
\text { to Powers Butte }\end{array}$ & $\begin{array}{l}\text { (e) Powers Butte } \\
\text { to Gillespie Dam }\end{array}$ & Mean \\
\hline $1868-83$ & 1.16 & 1.19 & 1.12 & 1.07 & 1.07 & 1.17 \\
\hline 1915 & 1.15 & & & & & \\
\hline 1926 & 1.12 & 1.12 & 1.12 & 1.09 & 1.14 & 1.16 \\
\hline 1929 & 1.14 & 1.13 & 1.08 & 1.08 & 1.13 & 1.15 \\
\hline 1937 & 1.20 & 1.17 & & & & \\
\hline 1941 & 1.16 & 1.09 & 1.09 & 1.01 & 1.10 & 1.13 \\
\hline 1944 & 1.15 & 1.19 & 1.19 & 1.06 & 1.23 & 1.21 \\
\hline 1957 & 1.23 & 1.23 & 1.08 & 1.03 & 1.32 & 1.22 \\
\hline 1961 & 1.12 & 1.23 & 1.07 & 1.05 & 1.31 & 1.22 \\
\hline 1971 & 1.21 & 1.25 & 1.12 & 1.06 & 1.31 & 1.23 \\
\hline 1976 & 1.17 & 1.18 & 1.11 & 1.06 & 1.11 & 1.17 \\
\hline 1979 & 1.06 & 1.21 & 1.13 & 1.06 & 1.11 & 1.17 \\
\hline 1980 & 1.21 & 1.23 & 1.15 & 1.06 & 1.20 & 1.22 \\
\hline Mean & 1.17 & 1.19 & 1.11 & 1.06 & 1.18 & 1.18 \\
\hline \multirow{2}{*}{$\begin{array}{l}\text { Standard } \\
\text { deviation }\end{array}$} & & & & & & \\
\hline & 0.05 & 0.05 & 0.04 & 0.02 & 0.09 & 0.03 \\
\hline
\end{tabular}

See Figure 3 for locations.

stability. Artificially induced sedimentation behind Gillespie Dam has produced reduced gradients, and low values of locational probability dominate the portion of the river where the upstream edge of the sediment wedge is found, near the upper right margin of Figure 4e.

Despite these unstable areas on the sediment wedge behind the dam, the probability maps shows a remarkable arrangement across the wedge with stable and unstable zones alternating with each other at about $3.2 \mathrm{~km}(2 \mathrm{mi})$ intervals. This regular spacing, a logical outcome of the geometric properties of the demand for sinuosity and the spacing of control factors, is in part a function of the sampling interval. Although the actual spacing may thus be slightly distorted, it undoubtedly exists.

The implications of the locational probabilities for planners and managers seeking to stabilize the river channel are that some reaches are already stable and probably require minimal investment. Other sections are inherently unstable and represent more likely candidates for control efforts.

Control efforts must also take into account the longterm sinuosity of the main flow channel, which has not deviated far from the mean value of 1.18 (Table 3 ). However, substantial spatial variation occurs in the value of sinuosity, with the channel displaying a consistently straight course between Robbins and Powers Buttes (sinuosity near 1.06), while the reach from Powers Butte to Gillespie Dam across the sediment wedge shows the highest values (up to 1.32). The highest mean value (1.19) occurs elsewhere, in section $b$ where even the high flow channel has semi-permanent meanders.

From the historical perspective, sinuosity of the main flow channel remained within a restricted range (1.13-1.17) between 1868 and 1940, but after the 1941 flood sinuosity was greater and fluctuated through a slightly wider range (1.171.23). Significantly, upstream dam construction reduced normal low flows to zero from 1938 onward. Fluctuations in sinuosity were especially large in the reach between Powers Butte and Gillespie Dam, which roughly corresponds to the area of the sediment wedge behind the dam. Sedimentation has reduced the gradient from the original 0.001231 to 0.000597 . Channel plugging and avulsion are most likely to occur on the most shallow gradients, and unstable, high values of sinuosity are the logical result.
The deposition of sediment in the plugging and avulsion process is accelerated by the growth of phreatophytes which introduce increased hydraulic roughness to the flow [Hadley, 1961; Graf, 1978]. The growth of phreatophytes, especially thickets of tamarisk, is most widespread in the channel section with the highest sinuosity values. In addition, the temporal trends in sinuosity for the entire study area closely parallel temporal trends in tamarisk growth (Figure 5). In the period from 1930 to 1940, sinuosity change lagged behind the rapidly increasing density of phreatophyte growth, but during the 1941 flood sinuosity dramatically increased, and thereafter the two variables appear to be closely linked.

A simple linear regression with sinuosity as the dependent variable and area of tamarisk coverage as the independent variable statistically demonstrates the degree of the association. The coefficient of correlation $(r)$ is 0.79 , and the coefficient of determination $\left(r^{2}\right)$ is 0.62 (with a level of significance of 0.0007 ), relatively high values in view of the complex nature of the geomorphic, hydraulic, and vegetation systems involved [Leopold et al., 1964, p. 274]. Clearly, the density of phreatophyte growth is critical in explaining the observed changes in sinuosity across the study area and through time.

The implications of the sinuosity analysis for planners and managers seeking to control the Gila River and similar channels are that despite radical changes in channel location, the overall channel configuration has maintained a sinuosity close to 1.18. Attempts to stabilize the channel must work with this channel behavior by building the mean sinuosity into plans and engineering works, rather than attempting to work against it by constructing straight channels with a sinuosity of 1.0. Design channels with straight configurations are doomed as the river seeks to reestablish the 'natural' sinuosity, a behavior observed in the failure of cleared and modified channels begun in 1957 upstream from Gillespie Dam. During subsequent floods the design channel was eliminated.

\section{CONCLUSIONS}

The broad outlines of channel change provided by locational probabilities and sinuosity measures must be viewed with some reservations. The data sources, for example, are limited so that the most recent channel configurations are better known than those of a century ago. Although channel con- 


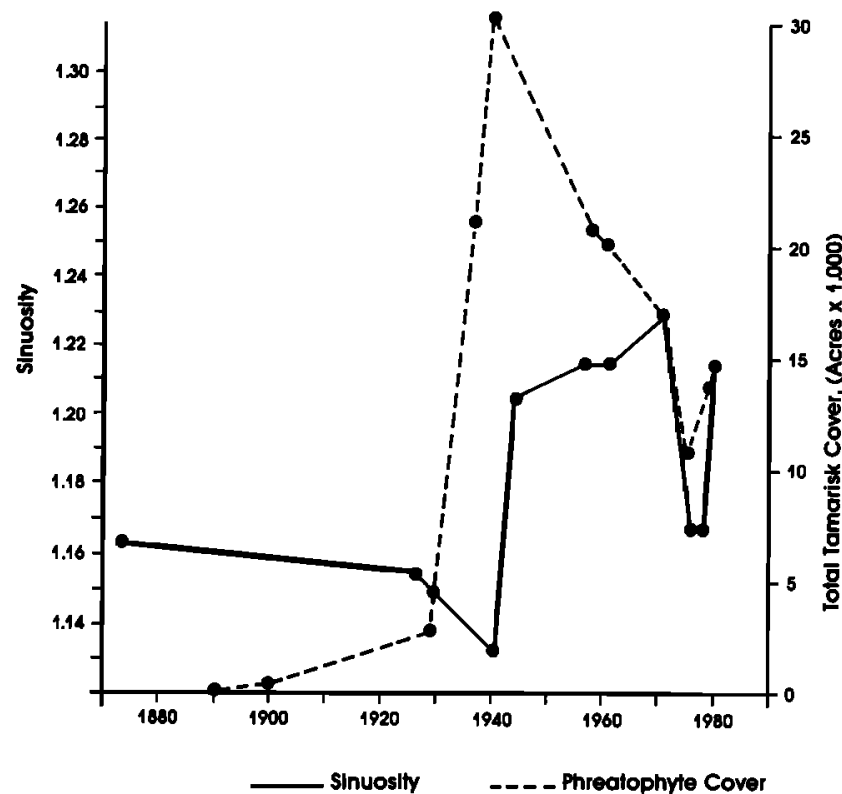

Fig. 5. Comparison of phreatophyte growth and channel sinuosity for the Gila River from the Salt River to Gillespie Dam.

figurations of the near future are likely to be influenced in part by present conditions, the inherent instability and lack of equilibrium conditions in the Gila River make knowledge of historical positions imperative because they appear to have a substantial likelihood of reoccurring. The data is weighted toward the recent conditions, but the conclusions may have some error built in because the system behavior may not be weighted in the same fashion.

The frequency of observations as determined by the data sources also poses a problem. The probability maps are based on the frequency of occurrence for channels within sampling units. It would be more convenient from a statistical sampling standpoint to obtain observations at annual or decadal intervals, but these data are not available. Since the changes occur only during floods, the sampling was stratified to insure that each between-flood period was included, but some periods went unobserved for lack of a suitable source of information. Had this information been included, the probability maps might have been somewhat different.

Although it is impossible to control the frequency of sampling through time, more selectivity is possible in sampling across space. The probability maps in this study were constructed from sampling lines spaced at $1.6 \mathrm{~km}(1 \mathrm{mi})$ intervals along the channel and divided into $164 \mathrm{~m}(500 \mathrm{ft})$ segments across the channel. More detailed maps would have resulted from a more dense sampling scheme or from the use of sampling squares that would blanket the channel area, but increasing resolution is accompanied by increasing processing requirements.

Finally, a basic underlying assumption for all the work reported here is that the past is a reliable guide to the future, hence a dependence on probabilistic approaches. When dealing with an unstable system, this approach seems prudent, but if large-scale interruptions occur in the area (construction of large levees, dams, or numerous bridges, extensive sand and gravel mines, wholesale, alteration of the phreatophyte communities, or a radical change in climate), the basic system may respond by adjusting its behavior to a totally new mode of op- eration. If this were to occur, past channel configurations probably would be unreliable in predicting future configurations.

With these reservations in mind, the research questions proposed at the beginning of this paper can be tentatively answered. First, using historical data sources, instability in braided, sand bed rivers can be mapped using locational probabilities that define zones of stability and hazardous zones of frequent channel migration. Second, the stable and unstable zones are arranged in such a way as to preserve a mean sinuosity under constraints imposed by bedrock controls and man-made structures. Interpretation and analysis of the behavior of streams with high flood discharge to annual discharge ratios depends on recognition of the catastrophic adjustments during floods with broad constraints rather than approaches that assume equilibrium conditions.

Acknowledgments. The investigation of instability in the braided, sand bed channel of the Gila River was made possible by the financial support of the U. S. Army Corps of Engineers, Los Angeles District, Phoenix Urban Studies Office. Supporting observations on the channel of the Fremont River, south central Utah, were financially assisted by a grant from the National Science Foundation, Earth Sciences Program (grant EAR-7727698). The opinions expressed in this paper are solely those of the author, and do not necessarily reflect the opinions or policies of the Corps of Engineers or the National Science Foundation. D. E. Smith (Department of Geography, Arizona State University) assisted in the data collections. Field visits and discussions with the following individuals provided input to the research effort: V. R. Baker (Department of Geology, University of Texas, Austin), W. B. Bull (Department of Geosciences, University of Arizona), J. E. Costa (Department of Geography, University of Denver) J. C. Knox (Department of Geography, University of Wisconsin, Madison), S. A. Schumm (Department of Earth Resources, Colorado State University), D. G. Smith (Department of Geography, University of Calgary), C. J. Sorenson (Department of Geography, University of Kansas), and S. W. Trimble (Department of Geography, University of California, Los Angeles). J. R. Dixon (U. S. Army Corps of Engineers, Phoenix) reviewed and provided useful comments on a draft of this paper.

\section{REFERENCES}

Aldridge, B. N., Floods of November 1965 to January 1966 in Gila River Basin, Arizona and New Mexico and adjacent basins in Arizona, Geol. Surv. Water-Supply Pap. U.S., 1850-C, 1970.

Brice, J. C., Channel patterns and terraces of the Loup Rivers in Nebraska, Geol. Surv. Prof. Pap. U.S., 422-D, 1964.

Corps of Engineers, Flood damage report, February 1979, U.S. Army Corps of Eng., Los Angeles Dist. Office Rep., 38 pp., $1979 a$.

Corps of Engineers, Flood damage report, November 1979, U.S. Army Corps of Eng., Los Angeles Dist. Office Rep., 41 pp., $1979 b$.

Euge, K. M., W. R. Lund, and J. D. Scott, Geology of the Palo Verde Nuclear Generating Station and adjacent areas, Maricopa County, Arizona, in Guide to the Geology of Central Arizona, edited by D. M. Burt and T. L. Péwe, pp. 115-129, Arizona Bureau of Geology and Mineral Technology, Tucson, 1978.

Graf, W. L., Fluvial adjustments to the spread of tamarisk in the Colorado Plateau region, Geol. Soc. Am. Bull., 89, p. 1491-1501, 1978.

Graf, W. L., Catastrophe theory as a model for change in fluvial systems, in Adjustments of the Fluvial System, edited by D. D. Rhodes and G. P. Williams, pp. 13-32, Dubuque Kendall/Hunt Publishers, Dubugue, lowa, 1979.

Graf, W. L., Riparian management: A flood control perspective, $J$. Soil Water Conserv., 35, 158-161, 1980.

Hadley, R. F., Influence of riparian vegetation on channel shape, northeastern Arizona, Geol. Surv. Prof. Pap. U.S., 424-C, 30-31, 1961.

Halpenny, L. C., and Greene, D. K., Water balance investigation of river bed, Salt and Gila Rivers, 23rd Avenue to Gillespie Dam, Arizona, unpublished report, Water Development Corporation, Tucson, Ariz., 1975. 
Hunt, C. B., Natural Regions of the United States, pp. 481-536, W. H. Freeman, San Francisco, Calif., 1974.

Leopold, L. B., and M. G. Wolman, River channel patterns: Braided, meandering, and straight, Geol. Surv. Prof. Pap. U.S., 282-B, 39-85, 1957.

Leopold, L. B., G. M. Wolman, and J. P. Miller, Fluvial Processes in Geomorphology, 522 pp., W. H. Freeman, San Francisco, Calif., 1964.

Pewé, T. L., Terraces of the lower Salt River Valley in relation to the late Cenezoic history of the Phoenix Basin, Arizona, in Guide to the Geology of Central Arizona, edited by D. M. Burt and T. L. Pewé, pp. 1-45, Arizona Bureau of Geology and Mineral Technology, Tucson, Ariz., 1978.

Prigogine, I., Time structure, and fluctuations, Science, 201, 777-785, 1978.

Schumm, S. A., Sinuosity of alluvial rivers on the Great Plains, Geol. Soc. Am. Bull., 74, 1089-1099, 1963.

Schumm, S. A., The Fluvial System, 338 pp., John Wiley, New York, 1977.

Shen, H. W., Modeling of Rivers, John Wiley, New York, 1979.

Smith, C. L., The Salt River Project: A Case Study in Cultural Adaption to an Urbanizing Community, 151 pp., University of Arizona Press, Tucson, 1972.
Smith, N. D., Transverse bars and braiding in the lower Platte River, Nebraska, Geol. Soc. Am. Bull., 82, 3407-3420, 1971.

Stevens, M. A., D. B. Simmons, and E. V. Richardson, Non-equilibrium river form, J. Hydraul. Div. Am. Soc. Civ. Eng., 101, 557-566, 1975.

Turner, R. M., Quantitative and historical evidence of vegetation changes along the upper Gila River, Arizona, Geol. Surv. Prof. Pap. U.S., 655-H, 1974.

Thomes, J., Structural instability and ephemeral channel behavior, $Z$. Geomorphol., 36, 233-244, 1980.

U. S. Department of Commerce, Climatic Atlas of the United States, 80 pp., U.S. Government Printing Office, Washington, D. C., 1968.

Wilson, E. D., A Resume of the Geology of Arizona, 140 pp., Arizona Bureau of Mines, Tucson, 1962.

Wilson, E. D., R. T. Moore, and H. W. Peirce, Geologic map of Maricopa County, Arizona, Ariz. Bureau of Mines, Tucson, 1957.

(Received January 28, 1981;

revised March 25, 1981;

accepted March 31, 1981.) 